\title{
REVIEW \\ Thermo-sensitivity and Photoperiod Sensitivity Genes Controlling Heading Time and Flower Bud Initiation in Sorghum, Sorghum bicolor Moench
}

\author{
Isao TARUMOTO ${ }^{1 *}$ \\ Laboratory of Genetics and Plant Breeding, Graduate School of Agriculture and Biological Sciences, \\ Osaka Prefecture University (Sakai, Osaka 599-8231, Japan)
}

\begin{abstract}
The timing of heading and flower bud initiation is critical for reproductive success. In sorghum (Sorghum bicolor Moench), which is a facultative short-day plant, we propose that the thermo-sensitivity and photoperiod sensitivity genes account for the relationship between heading time and the environment. In experiments in fields and growth cabinets, the heading time of cultivars such as cv.Hiromidori accelerated with reduction in total leaf number by exposure to temperatures lower than $20^{\circ} \mathrm{C}$ (i.e., the opposite phenomenon occurs at over $20^{\circ} \mathrm{C}$ ); these cultivars were designated as B-type cultivars. The flower bud initiation of cultivars such as cv.Tentaka was induced by critical daylength below 12.25 hours; these cultivars were designated as C-type cultivars. In the inheritance study using populations derived from hybrids of B-type cultivars, thermo-sensitivity for heading response was controlled by a monogenic dominant gene $(T)$ of late over early heading. The existence of two photoperiod sensitivity genes, $D_{l}$ and $D_{2}$, which show complementary dominant effects, was found in populations derived from hybrids of $\mathrm{C}$ type cultivars, and the heading response of $\mathrm{C}$ type cultivars was expressed by the interaction both of a dominant thermo-sensitive gene $(T)$ and complementary dominant photoperiod sensitivity genes $\left(D_{1}, D_{2}\right)$. AFLP and RFLP analysis suggested that $T$ was located at a genetic distance of $4.0 \mathrm{cM}$ from the AFLP16 marker locus on chromosome 6.
\end{abstract}

Discipline: Plant breeding / Genetic resources

Additional key words: AFLP, complementary gene effect, daylength, heading response, inheritance

\section{Introduction}

Flower bud initiation is the developmental turning point from the vegetative to the reproductive phase in plants. The timing of heading and flowering is critical for reproductive success, and the relationship between the developmental stage of plants and environmental factors such as photoperiod and temperature has been studied ${ }^{5,10,11,25}$.

Sorghum is a facultative short-day plant originating in tropical Africa, ${ }^{5,10,11}$. The differentiation of sorghum cultivars associated with sorghum's adaptation to temperate environments and/or from low to high altitudes has involved changes in heading response for successful reproduction and grain production ${ }^{10}$. In sorghum, the natural mutations from photoperiod-sensitive to insensitive types and/or from thermo-sensitive to thermo-neutral types are considered to be genetic factors for changing heading response $e^{14,15}$.

Sorghum cultivars adapted to temperate/sub-tropical climates in the United States exhibited a flowering time of 45 to 100 days, and four maturity genes, $M a_{1}$ to $M a_{4}$, were used to explain the varietal differences of flowering time ${ }^{10}$. Miller et al. ${ }^{6}$ reported that the dominant genes of $M a_{1}$ and $M a_{2}$ expressed photoperiod sensitivity in a critical photoperiod of $13 \mathrm{~h}$. Almost all sorghums cultivated in Japan are $F_{1}$ hybrids produced by crosses between male-sterile grain sorghum strains and other strains such as hegari, sudangrass and sorgo, all of which have temperate adaptation ${ }^{14}$. The heading response of these $F_{1}$ hybrids has been explained on the basis of maturity genes as described by Major et al. ${ }^{5}$, Miller et al. ${ }^{6}$, and Quinby ${ }^{10}$, although there was variation. The heading time of the $F_{1}$ hybrids was between those of cross parents ${ }^{14}$ and were less than that of 100-day Milo, which exhibited the latest flowering time with the genotype

\footnotetext{
Present address:

${ }^{1}$ Tsukuba, Ibaraki 305-0051, Japan

*Corresponding author: e-mail i_taru2006@ybb.ne.jp

Received 22 March 2007; accepted 21 June 2010.
} 
$M a_{1} M a_{1} \mathrm{Ma}_{2} \mathrm{Ma}_{2} \mathrm{Ma}_{3} \mathrm{Ma}_{3} \mathrm{Ma}_{4} \mathrm{Ma}_{4}$.

Two exceptions, however, were observed. One was observed in hybrids such as cv.Hiromidori (Norin ko-2: Tx390 x Regs.Hegari ${ }^{13}$. The heading response of cv.Hiromidori was similar to that of Combine hegari ${ }^{11}$, but no clear genetic explanation was made in Quinby et al. ${ }^{11}$ or Tarumoto $^{13,14}$ using Quinby's maturity genes ${ }^{10}$. The other is in new hybrids ${ }^{3}$, cv.Tentaka and cv.Kazetachi, developed by hybridization between grain sorghum lines with very early maturity and photoperiod insensitivity. The heading response of cv.Tentaka and cv.Kazetachi, which exhibited strong photoperiod sensitivity and very late heading time e $^{3,15}$, cannot be explained by Quinby's maturity genes ${ }^{10}$. To account for the observed heading response of the above two kinds of hybrid cultivars, Tarumoto et al. ${ }^{16}$ proposed a thermo-sensitivity gene $(T)$ and a photoperiod sensitivity gene $(D)$. In order to prove the hypothesis, physiological and genetic studies of thermo-sensitivity and photoperiod sensitivity in sorghum were conducted ${ }^{13,16-22}$. This report deals with the heading response and/or flower bud initiation of sorghum cultivars related to temperature and daylength, and the inheritance of thermo-sensitivity and photoperiod sensitivity in hybrid sorghum.

\section{Genetic variation and the effect of the environment on the heading time of sorghum}

Quinby ${ }^{10}$ and Quinby et al. ${ }^{11}$ characterized four maturity gene loci, $M a_{1}, M a_{2}, M a_{3}$ and $M a_{4}$, for heading/flowering variation in sorghum cultivars adapted to temperate/ sub-tropical climates in the United States, and the loci have accounted for much of the heading variation in sorghum. However, heading variation that cannot be explained by the four maturity loci ${ }^{5,10-11}$ was observed in cv.Hiromidori ${ }^{14}$, and cv.Tentaka and cv.Kazetachi ${ }^{3}$. Therefore, I studied the heading response in sorghum cultivars ${ }^{16}$ and showed the effect of the environment on heading time and flower bud initiation in $F_{1}$ hybrids such as cv.Hiromidori, cv.Tentaka and cv.Kazetachi ${ }^{20-21}$.

To examine genetic variation in heading response, four $\mathrm{F}_{1}$ hybrids (cv.Suzuho, cv.Hiromidori, cv.Tentaka and cv.Kazetachi) and their cross parents shown in Table 1 were grown at three locations (Shioziri, Nagano, latitude $36^{\circ} 10^{\prime}$ N; Sakai, Osaka, latitude 34³3' N; Ohsumi, Kagoshima, latitude $31^{\circ} 23^{\prime} \mathrm{N}$ ) using four planting dates at 20-day intervals (20 May, 10 June, 1 July, and 20 July) in $1996^{16}$. In all cases, the daylength during the period of 40 days after planting was more than $13 \mathrm{~h}$. Under these long daylength, the cultivars were classified into the following three types according to their heading response ${ }^{16}$ : A-type (Chohin232, Tx3048, cv.Suzuho, Chohin1682 and Tx390): heading response was neutral to temperature and daylength; B-type (MS138, MS79, Regs.Hegari and cv.Hiromidori): heading time was accelerated by a minimum temperature below $20^{\circ} \mathrm{C}$ after the seventh leaf stage; and C-type (cv.Kazetachi and cv.Tentaka): flower bud initiation was induced by less than $12.5 \mathrm{~h}$ daylength after the seventh leaf stage. In a principal component analysis on days to heading resulted in 12 experiments ( 3 locations $\mathrm{x} 4$ plantings), the cultivars were clearly classified into A, B and C types as shown in Fig. 1. From the result, it was assumed that a thermo-sensitivity gene $(t)$ and a photoperiod sensitivity gene $(D)$ were present

Table 1. Sorghum cultivars used in this study

\begin{tabular}{|c|c|c|c|}
\hline Cultivar & Origin & $\begin{array}{l}\text { Breeding (Introduction) } \\
\text { organization }\end{array}$ & $\begin{array}{l}\text { Genotype } \\
\left.\text { for maturity }{ }^{a}\right)\end{array}$ \\
\hline Tx3048 & Redbine sel.3048 & (Texas A\&M Univ., U.S.A.) & $m a_{1} M a_{2} m a_{3} M a_{4}$ \\
\hline Chohin1684 (1) ${ }^{b)}$ & Senkinshiro & (Nagano Animal Ind. Exp. Sta., Japan) & -- \\
\hline Suzuho & $\mathrm{F}_{1}(\mathrm{~T} \times 3048 \times 1)$ & Nagano Animal Ind. Exp. Sta., Japan & -- \\
\hline Tx390 & Texas Blackhull Kafir & (Texas A\&M Univ., U.S.A.) & $m a_{1} M a_{2} M a_{3} M a_{4}$ \\
\hline Regs.Hegari (2) $\left.{ }^{b}\right)$ & Hegari & (Texas A\&M Univ., U.S.A.) & $M a_{1} M a_{2} M a_{3} m a_{4}$ \\
\hline Hiromidori & $\mathrm{F}_{1}(\mathrm{~T} \times 390 \times 2)$ & Hiroshima Agr. Exp. Sta., Japan & -- \\
\hline MS175 & 932233 & Purdue Univ., U.S.A. & -- \\
\hline Chohin $237(3)^{\text {b) }}$ & Daikoukaku & (Nagano Animal Ind. Exp. Sta., Japan) & -- \\
\hline Natsuibuki & $\mathrm{F}_{1}(\mathrm{MS} 175 \times 3)$ & Nagano Animal Ind. Exp. Sta., Japan & -- \\
\hline MS79 & IS2930 & Purdue Univ., U.S.A. & -- \\
\hline Chohin232 (4) ${ }^{\mathrm{b})}$ & 74LH3213 & CIMMYT, Mexico & -- \\
\hline Tentaka & $\mathrm{F}_{1}(\mathrm{MS} 79 \times 4)$ & Nagano Animal Ind. Exp. Sta., Japan & -- \\
\hline MS138 & 932233 & Purdue Univ., U.S.A. & -- \\
\hline Kazetachi & $\mathrm{F}_{1}(\mathrm{MS} 138 \times 4)$ & Nagano Animal Ind. Exp. Sta., Japan & -- \\
\hline
\end{tabular}

a) After Quinby (1967)

b) Figures in parentheses following variety show the number of corresponding male parents 


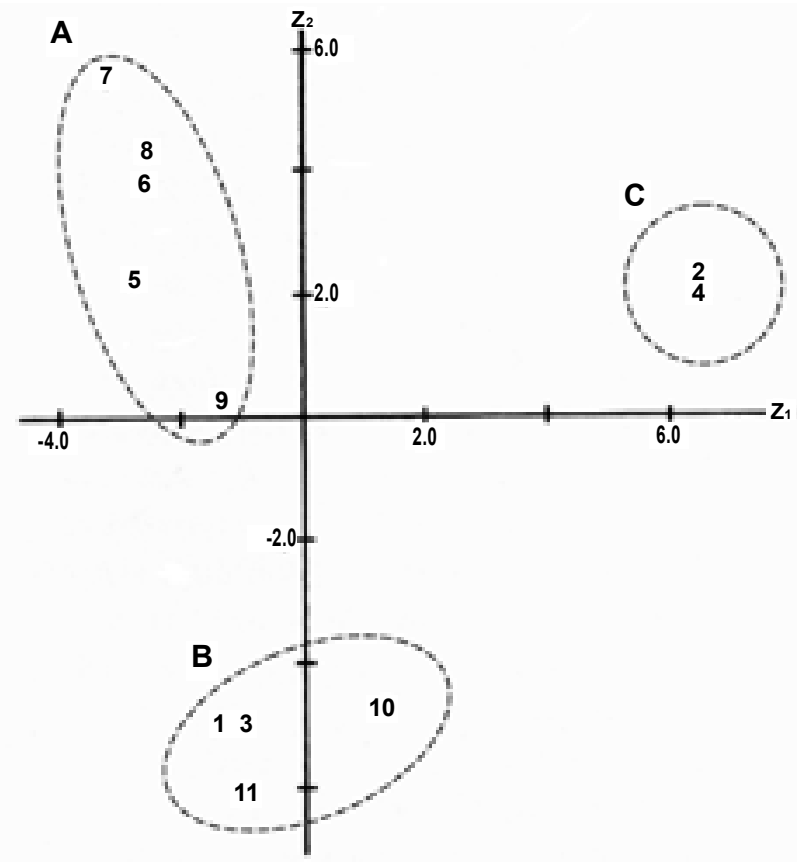

Fig. 1. Scatter diagram of 11 sorghum cultivars according to the first $\left(Z_{1}\right)$ and second $\left(Z_{2}\right)$ principal component scores extracted by a principal component analysis on day to heading (3 experimental places $x 4$ planting dates)

Note: 1) 3 experimental places: Shiogiri, Nagano; Sakai, Osaka; Kanoya, Kagoshima.

2) 4 planting dates: May 20, June 10, July 1 , and July 20 in 1996.

3) Figures in the diagram show the entry number of cultivars.

A-type: 5.Chohin232, 6.Tx3048, 7.Suzuho, 8.Chohin1684, 9.Tx390

B-type: 1.MS138, 3.MS79, 10.Hiromidori, 11.Regs.Hegari.

C-type: 2.Kazetachi, 4.Tentaka

and that $t t$ displayed recessive epistasis to $D$-.

In order to show the relationship between heading type and the environment, four B-type cultivars (MS138, MS79, Regs.Hegari, and cv.Hiromidori) and two A-type cultivars (Tx390 and Senkinshiro) were studied at various daylengths and temperatures in growth cabinets ${ }^{2,420}$. At a continuous high temperature of $25^{\circ} \mathrm{C} / 25^{\circ} \mathrm{C}$ (day/night), the days to flower bud initiation (DFBI) of all six cultivars were noticeably shortened in $12.0 \mathrm{~h}$ daylength, compared to $12.5 \mathrm{~h}$ and $14.0 \mathrm{~h}$ daylength, and the DFBI in $12.5 \mathrm{~h}$ and $14.0 \mathrm{~h}$ daylength were almost the same. In daylength longer than 12.5 $\mathrm{h}$, the DFBI of B-type were accelerated 10 to 26 days in $30^{\circ} \mathrm{C} / 20^{\circ} \mathrm{C}($ day/night $)$ temperature compared to a continuous temperature of $25^{\circ} \mathrm{C} / 25^{\circ} \mathrm{C}($ day/night $)$. The acceleration in flower bud initiation at low night temperature (minimum temperature) in long daylength increased with the reduction in night temperature from $20^{\circ} \mathrm{C}$ to $15^{\circ} \mathrm{C}$, and this was linked with the reduction of total leaf number until flower bud initiation and heading ${ }^{20}$. In other words, reduction in total leaf number by exposure to minimum temperatures lower than $20^{\circ} \mathrm{C}$ induced earlier flower bud initiation in B-type cultivars such as cv.Hiromidori (i.e., the opposite phenomenon occurs at over $20^{\circ} \mathrm{C}$ ). As for the heading response of B-type cultivars, Uozumi ${ }^{26}$ and Uozumi et al. ${ }^{23,24,25}$ obtained the same results and noted that the effect of minimum temperatures lower than $20^{\circ} \mathrm{C}$ became apparent after the eighth leaf stage. The heading response of B-type cultivars is summarized in Table 2.

To find the critical daylength and its effective timing for C-type cultivars, cv.Kazetachi and their cross parents were tested for flower bud initiation in five different daylengths and two different temperature conditions in growth cabinets $^{4,21}$. From the results, the threshold daylength for flower bud initiation of cv.Kazetachi was found to be 12.25 $\mathrm{h}$, and the $12.25 \mathrm{~h}$ daylength was effective 10 to 30 days after emergence of seedling (third to fifth leaf stage) ${ }^{21}$. The heading response of C-type cultivars such as cv.Kazetachi is summarized in Table 2. Also, as shown in Table 2, the optimum daylength of A, B and C-type cultivars to flower bud initiation was $12.0 \mathrm{~h}^{21}$.

\section{Inheritance of thermo-sensitivity and photoperiod sensitivity in B- and C-type hybrid sorghum}

In the previous section, the unique heading response of B- and C-type cultivars were considered to be genetic ones and their response to the environmental effects were revealed ${ }^{20-21}$. However, there had been no inheritance studies of thermo-sensitivity and photoperiod sensitivity ${ }^{16}$, so I studied the inheritance mode of thermo-sensitivity and photoperiod sensitivity genes ${ }^{16-19}$ in field conditions in long daylength $(>13 \mathrm{~h})$ and at temperatures over $20^{\circ} \mathrm{C}$ for at least 40 days after sowing ${ }^{1}$, and identified the chromosomal location of the thermo-sensitivity gene using AFLP markers ${ }^{8,9}$.

\section{Inheritance of a thermo-sensitivity gene controlling the heading response of B-type cultivars}

A thermo-sensitivity gene in sorghum accounts for the acceleration of heading response when plants are exposed to temperatures lower than $20^{\circ} \mathrm{C}$ in long daylength ${ }^{15,16}$. In order to identify the inheritance mode of the thermo-sensitivity gene, the $\mathrm{F}_{1}, \mathrm{~F}_{2}, \mathrm{~F}_{3}$ and $\mathrm{BC}_{1} \mathrm{~F}_{1}$ populations of $\mathrm{cv}$. Hiromidori and cv.Natsuibuki (Norin Ko-9) in Table 3 were evaluated for the days to emergence of flag leaf (DEFL) in field conditions in long daylength $(>13 \mathrm{~h}$ ) and at temperatures over $20^{\circ} \mathrm{C}$ for 51 days after sowing in 1999 and $2000^{17}$. The $\mathrm{F}_{1}$ hybrids, cv.Hiromidori : Tx390 (early) x Regs. Hegari (late), and cv.Natsuibuki : MS175 (late) x Daikoukaku (early), showed the same heading response as B-type cultivars such as Regs.Hegari and MS175, which showed a delay in DEFL at temperatures over $20^{\circ} \mathrm{C}$, sug- 
Table 2. Types of heading response and/or flower bud initiation (FBI), their relationship with minimum temperature (Min-T) and daylength (DL), and the genotypes predicted by the heading response to environmental condition

\begin{tabular}{|c|c|c|c|}
\hline & $\mathrm{DL}>12.5 \mathrm{~h}$ & $\mathrm{DL}<12.25 \mathrm{~h}$ & $\mathrm{DL} \leqq 12.0 \mathrm{~h}$ \\
\hline Min- $\mathrm{T}>20^{\circ} \mathrm{C}$ & $\begin{array}{l}\text { A-type }(t t d d, t t D-)^{1)} \text { : } \\
\text { Heading emergence (HE) of } \\
\text { almost cultivars including } \\
\text { Suzuho, MS79, Tx3048, } \\
\text { Chohin } 1684, T \times 3048, T x- \\
390 \text { \& Chouhin } 237 \\
\text { is accelerated, } \\
\text { but HE of B-type cultivars } \\
\text { like Hiromidori is delayed }\end{array}$ & (not yet observed) & $\begin{array}{l}\text { In all cultivars of } \\
(\mathrm{A}+\mathrm{B}+\mathrm{C}) \text { type, FBI } \\
\text { is induced when the } \\
\text { vegetative growth } \\
\text { is attained, and earlier } \\
\mathrm{HE} \text { is observed }\end{array}$ \\
\hline Min- $\mathrm{T} \leqq 20^{\circ} \mathrm{C}$ & $\begin{array}{l}\text { B-type }(T-d d)^{1)} \text { : } \\
\text { HE of Hiromidori, Natsuibuki, } \\
\text { Reg.Hegari, MS138 \& MS175 } \\
\text { is accelerated }\end{array}$ & $\begin{array}{l}\text { C-type }(T-D-)^{1)} \text { : } \\
\text { FBI of Kazetachi \& } \\
\text { Tentaka is induced }\end{array}$ & Ditto in the above \\
\hline
\end{tabular}

1) In genotypes tentatively predicted by the heading response, A-type : $t d d d$, $t t D$-, B-type :T- $d d$, C-type :T-D-.

Note) Relationship between thermo-sensitivity gene $(T->t t)$ and photoperiod sensitivity gene $(D->d d)$ : (a.) $t t$ shows recessive epistasis over $D D$ and $D d$, and the genotype with $t t D$ - is neutral to long daylength, (b.) $T$ - and $D$ - act complementarily, and flower bud initiation of the genotype $T-D$ - is induced only under a short daylength less than $12.25 \mathrm{~h}$.

Table 3. DEFL(days to emergence of flag leaf) in parental varieties included Hiromidori and Natuibuki, and segregation pattern for DEFL in $F_{2}$ and backcross populations of Hiromidori and Natuibuki during the summer of 2000

\begin{tabular}{|c|c|c|c|c|c|c|}
\hline \multirow{2}{*}{$\begin{array}{l}\text { Variety and/or } \\
\text { population }\end{array}$} & \multirow{2}{*}{$\begin{array}{l}\text { Total } \\
\text { number }\end{array}$} & \multicolumn{2}{|c|}{ No. of plants segregated into } & \multirow{2}{*}{$\begin{array}{c}\text { Expected ratio } \\
\text { (early : late) }\end{array}$} & \multirow[b]{2}{*}{$\chi^{2}$} & \multirow[b]{2}{*}{$\mathrm{P}$} \\
\hline & & Early & Late & & & \\
\hline & & $\left.(\text { early }<60)^{b}\right)$ & (late $>60)$ & & & \\
\hline Tx390 & 19 & $19(45)^{\mathrm{b})}$ & 0 & & & \\
\hline Regs.Hegari (RH) & 16 & 0 & $16(75)$ & & & \\
\hline Hiromidori & 22 & 0 & $22(78)$ & & & \\
\hline $\mathrm{F}_{2}$ & 266 & 56 & 210 & $1: 3$ & 2.210 & $0.10-0.25$ \\
\hline $\mathrm{BC}_{1} \mathrm{~F}_{1}\left(\mathrm{~T} \times 390 \times \mathrm{F}_{1}\right)^{\mathrm{a})}$ & 185 & 84 & 101 & $1: 1$ & 1.560 & $0.30-0.10$ \\
\hline \multirow[t]{2}{*}{$\mathrm{BC}_{1} \mathrm{~F}_{1}\left(\mathrm{~F}_{1} \times \mathrm{RH}\right)^{\mathrm{a})}$} & 146 & 0 & 146 & no segregation & & \\
\hline & & $(\text { early }<46)^{\text {b) }}$ & (late $>46)$ & & & \\
\hline MS175 & 30 & 0 & $30(62)^{b)}$ & & & \\
\hline Daikoukaku (DK) & 23 & $23(34)$ & 0 & & & \\
\hline Natsuibuki & 25 & 0 & $25(64)$ & & & \\
\hline $\mathrm{F}_{2}$ & 209 & 58 & 151 & $1: 3$ & 0.834 & $0.50-0.30$ \\
\hline $\mathrm{BC}_{1} \mathrm{~F}_{1}\left(\mathrm{MS} 175 \times \mathrm{F}_{1}\right)^{\mathrm{a})}$ & 96 & 0 & 96 & no segregation & & \\
\hline $\mathrm{BC}_{1} \mathrm{~F}_{1}\left(\mathrm{~F}_{1} \times \mathrm{DK}\right)^{\mathrm{a})}$ & 173 & 80 & 93 & $1: 1$ & 0.977 & $0.50-0.30$ \\
\hline
\end{tabular}

a) $\mathrm{BC}_{1} \mathrm{~F}_{1}\left(\mathrm{~T} \times 390 \times \mathrm{F}_{1}\right)$ were derived from a cross between $\mathrm{Tx} 390$ and Hiromidori. $\mathrm{BC}_{1} \mathrm{~F}_{1}\left(\mathrm{~F}_{1} \times \mathrm{RH}\right)$ were derived from a cross between hand-emasculated Hiromidori and Regs.Hegari.

$\mathrm{BC}_{1} \mathrm{~F}_{1}\left(\mathrm{MS} 175 \times \mathrm{F}_{1}\right)$ were derived from a cross between MS175A and Natsuibuki. $\mathrm{BC}_{1} \mathrm{~F}_{1}\left(\mathrm{~F}_{1} \times \mathrm{DK}\right)$ were derived from a cross between hand-emasculated Natsuibuki and Daikoukaku.

b) Figures in parentheses show DEFL.

gesting the presence of a dominant thermo-sensitivity gene. In two different $F_{2}$ populations, the segregation of early and late plants for DEFL fitted the expected $1: 3$ ratio (Table $3)^{17}$, indicating that a single dominant gene induced late heading. The inheritance mode was confirmed in two dif- ferent $\mathrm{BC}_{1} \mathrm{~F}_{1}$ populations (Table 3$)^{17}$, where the expected 1 : 1 (early : late) ratio was observed in the segregation of the $\mathrm{BC}_{1} \mathrm{~F}_{1}$ of $\left(\mathrm{T} \times 390 \times \mathrm{F}_{1}\right)$ and $\left(\mathrm{F}_{1} \times\right.$ Daikoukaku). As expected, no segregation was observed in $\mathrm{BC}_{1} \mathrm{~F}_{1}$ populations of $\left(\mathrm{F}_{1} \mathrm{x}\right.$ Regs.Hegari) and (MS175 $\times \mathrm{F}_{1}$ ). These results suggest that 
Table 4. Response for DEFL of parental varieties included Tentaka and Kazetachi, and segregation pattern for DEFL in $F_{2}$ and backcross populations of Tentaka and Kazetachi during the summer of 2000 at Sakai, Osaka Prefecture University

\begin{tabular}{|c|c|c|c|c|c|c|c|}
\hline \multirow{2}{*}{$\begin{array}{l}\text { Varieties and/or } \\
\text { population }\end{array}$} & \multirow{2}{*}{$\begin{array}{l}\text { Total } \\
\text { number }\end{array}$} & \multicolumn{3}{|c|}{ No. of plants segregated into } & \multirow{2}{*}{$\frac{\text { Expected ratio }}{\text { (early : middle : late) }}$} & \multirow[b]{2}{*}{$\chi^{2}$} & \multirow[b]{2}{*}{$\mathrm{P}$} \\
\hline & & early & middle & late & & & \\
\hline & & $(<51)^{\text {b) }}$ & $(51-99)$ & $(>99)$ & & & \\
\hline MS79 & 14 & 0 & $14(56)^{b)}$ & 0 & & & \\
\hline Chohin232 & 15 & $15(38)$ & 0 & 0 & & & \\
\hline Tentaka & 10 & 0 & 0 & $10(105)$ & & & \\
\hline $\mathrm{F}_{2}$ & 265 & 27 & 132 & 106 & $7: 30: 27$ & 1.91 & $0.50-0.25$ \\
\hline \multirow[t]{2}{*}{$\mathrm{BC}_{1} \mathrm{~F}_{1}{ }^{\mathrm{a})}$} & 286 & 92 & 126 & 68 & $1: 2: 1$ & 5.33 & $0.10-0.05$ \\
\hline & & $(<51)^{\mathrm{b})}$ & $(51-99)$ & $(>99)$ & & & \\
\hline MS138 & 13 & 0 & $13(57)^{b)}$ & 0 & & & \\
\hline Chohin232 & 16 & $10(38)$ & 0 & 0 & & & \\
\hline Kazetachi & 10 & 0 & 0 & $10(105)$ & & & \\
\hline $\mathrm{F}_{2}$ & 353 & 45 & 166 & 142 & $7: 30: 27$ & 1.38 & $0.75-0.50$ \\
\hline $\mathrm{BC}_{1} \mathrm{~F}_{1}{ }^{\mathrm{a})}$ & 103 & 22 & 60 & 21 & $1: 2: 1$ & 0.24 & $0.90-0.75$ \\
\hline
\end{tabular}

a) $\mathrm{BC}_{1} \mathrm{~F}_{1}$ were derived from crossing hand-emasculated Kazetachi and Tentaka by Chohin 232 .

b) Figures in parentheses show DEFL

the thermo-sensitivity inducing late heading in B-type cultivars is controlled by a monogenic dominant gene of late over early heading, and the symbol $T T$ is assigned to the genotype in which flower bud initiation is accelerated by exposure to temperatures lower than $20^{\circ} \mathrm{C}$ in long daylength ${ }^{17}$.

\section{Inheritance of photoperiod sensitivity and thermo-sensitivity genes controlling the heading response in $\mathrm{C}$-type cultivars}

The photoperiod sensitivity gene in sorghum postpones flower bud initiation in C-type cultivars until the cultivars meet in a short daylength below $12.5 \mathrm{~h}$ after the seventh leaf stage $^{15}$. To identify the inheritance mode in C-type cultivars, the $\mathrm{F}_{1}, \mathrm{~F}_{2}, \mathrm{BC}_{1} \mathrm{~F}_{1}$ and $\mathrm{BC}_{1} \mathrm{~F}_{2}$ populations of cv.Tentaka and cv.Kazetachi in Table 4 were evaluated for days to emergence of flag leaf (DEFL) in field conditions in long daylength $(>13 \mathrm{~h})$ and at minimum temperatures over $20^{\circ} \mathrm{C}$ for 51 days after sowing in 1999 and $2000^{18}$. The $F_{1}$ hybrids, cv.Tentaka (MS79 x Chohin232), and cv.Kazetachi (MS138 $\mathrm{x}$ Chohin232), exhibited strong photoperiod sensitivity and very late DEFL, although their parental cultivars were photoperiod insensitive (Table 2 and 4$)^{18}$. In two different $F_{2}$ populations, the segregation of plants for DEFL fitted the expected $7: 30: 27$ (early : middle : late) ratio under the three genes hypothesis of photoperiod sensitivity and thermo-sensitivity (Table 4$)^{18}$, designating $T t D_{1} d_{1} D_{2} d_{2}$ for cv.Tentaka and cv.Kazetachi (Table 5) ${ }^{18}$. In addition, the expected ratio of (early : middle : late $=1: 2: 1$ ) was observed in the segregation of $\mathrm{BC}_{1} \mathrm{~F}_{1}$ of (cv.Tentaka $\mathrm{x}$ Chohin232) and (cv.Kazetachi x Chohin232) ${ }^{18}$. These results suggested that two photoperiod sensitivity genes, $D_{1}$ and $D_{2}$, which showed a complementary dominant effect, were effective, and the heading response of C-type hybrids, cv.Tentaka and cv.Kazetachi, were expressed by the interactive regulation both of a dominant thermo-sensitivity gene $(T)$ and complementary dominant photoperiod sensitivity genes $\left(D_{1}, D_{2}\right)^{18}$, that is the genotype $T t D_{1} d_{1} D_{2} d_{2}$.

Rooney and Aydin ${ }^{12}$ identified other maturity genes $\left(M a_{5}\right.$ and $\left.M a_{6}\right)$, and noted that $\mathrm{F}_{1}$ hybrids crossed between sorghum cultivars carrying $M a_{5} m a_{6}$ and the special inbred line carrying $m a_{5} M a_{6}$ had a critical daylength of $12.33 \mathrm{~h}$. Ctype cultivars with genotype $T t D_{1} d_{1} D_{2} d_{2}{ }^{18-19,21}$ and hybrids ${ }^{12}$ carrying $M a_{5} M a_{6}$ genes exhibited almost the same photoperiod sensitivity. However, the hybrid with a $t t D_{1} d_{1} D_{2} d_{2}$ genotype exhibited a critical daylength of $13.0 \mathrm{~h}^{18,19}$, and C-type cultivars with a $T t D_{1} d_{1} D_{2} d_{2}$ genotype exhibited a critical daylength of $12.25 \mathrm{~h}$ with the interaction between $D_{1} D_{2}$ and $T$ genes ${ }^{18,19,21}$. Therefore, the photoperiod sensitivity, $D_{l}$ and $D_{2}$, were considered to differ from the maturity genes, $M a_{5}$ and $M a_{6}$, in their genetic regulation and critical daylength.

The heading types of cultivars used in this experiment and their genotypes for thermo-sensitivity and photoperiod sensitivity are listed in Table $5^{18}$.

\section{Identification of the chromosomal location of the thermo-sensitivity gene using AFLP markers}

In order to identify the thermo-sensitivity gene $(T)$ in B-type sorghum cultivars using AFLP markers, DNA markers linked to the $T$ gene were screened by bulk analysis with amplified fragment-length polymorphism (AFLP). Fourteen dominant markers and one co-dominant marker were 
Table 5. Types of heading response in Table 2 and genotypes estimated from Table 3 and 4

\begin{tabular}{|c|c|c|c|c|c|}
\hline Cross & Cultivar & $\begin{array}{l}\text { Type of heading } \\
\text { response }\end{array}$ & Genotype & & \\
\hline Female & Tx390 & A & $t t d_{1} d_{1} d_{2} d_{2}$ & \multirow{3}{*}{\multicolumn{2}{|c|}{ or $\quad t t d_{1} d_{1} D_{2} D$}} \\
\hline Male & Regs.Hegari & B & $T T d_{1} d_{1} D_{2} D_{2}$ & & \\
\hline $\mathrm{F}_{1}$ & Hiromidori & $\mathrm{B}$ & $T t d_{1} d_{1} D_{2} d_{2}$ & & \\
\hline Female & MS175 & $\mathrm{B}$ & $T T d_{1} d_{1} D_{2} D_{2}$ & \multirow{9}{*}{ or } & \multirow{9}{*}{$t t d_{1} d_{1} D_{2} D_{2}$} \\
\hline Male & Chouhin 237 & A & $t t d_{1} d_{1} d_{2} d_{2}$ & & \\
\hline $\mathrm{F}_{1}$ & Natsuibuki & B & $T t d_{1} d_{1} D_{2} d_{2}$ & & \\
\hline Female & MS79 & $\mathrm{B}$ & $\operatorname{TTd}_{1} d_{1} D_{2} D_{2}$ & & \\
\hline Male & Chohin232 & A & $t t D_{1} D_{1} d_{2} d_{2}$ & & \\
\hline $\mathrm{F}_{1}$ & Tentaka & $\mathrm{C}$ & $T t D_{1} d_{1} D_{2} d_{2}$ & & \\
\hline Female & MS138 & $\mathrm{B}$ & $T T d_{1} d_{1} D_{2} D_{2}$ & & \\
\hline Male & Chohin232 & A & $t t D_{1} D_{1} d_{2} d_{2}$ & & \\
\hline $\mathrm{F}_{1}$ & Kazetachi & $\mathrm{C}$ & $T t D_{1} d_{1} D_{2} d_{2}$ & & \\
\hline
\end{tabular}

screened from 1024 AFLP markers and seven of them could be assigned to a linkage map. Linkage analysis using 33 individuals from the $\mathrm{BC}_{1} \mathrm{~F}_{2}$ population, which were clearly classified as $t t$ or $T$-, showed that the $T$ locus for thermosensitivity was located at $3.2 \mathrm{cM}$ distance from the marker AFLP $16^{8}$. Restriction fragment length polymorphism (RFLP) analysis was carried out to find the more critical region of AFLP16 by comparison with 145 RFLP markers already mapped on the authentic sorghum genetic map ${ }^{7}$. As shown in Fig. 2, the locus for thermo-sensitivity was estimated to be located on chromosome 6 at a distance of 4.0 cM from the AFLP 16 marker?.

\section{Conclusion}

This report deals with the heading response and/or flower bud initiation in two kinds of hybrid cultivars (B and
C types), which were not accounted for by the maturity genes of Quinby ${ }^{10}$ and Quinby et al. ${ }^{11}$ The heading response of B-type cultivars such as cv.Hiromidori accelerated with a reduction in total leaf number at minimum temperatures lower than $20^{\circ} \mathrm{C}$ (i.e., the opposite phenomenon occurs at over $20^{\circ} \mathrm{C}$ ). C-type cultivars such as cv.Tentaka and cv.Kazetachi had a critical daylength of $12.25 \mathrm{~h}$ and flower bud initiation was induced in a daylength below $12.25 \mathrm{~h}$ at minimum temperatures lower than $20^{\circ} \mathrm{C}$. Effective timing in $12.25 \mathrm{~h}$ daylength was 10 to 30 days after emergence of seedling (third to fifth leaf stage). These results provided useful information for improving the yield potential and cultivation of sorghum ${ }^{24-27}$.

In the inheritance study, thermo-sensitivity for heading response was controlled by a monogenic dominant gene $(T)$ of late over early heading. The heading response of C-type cultivars was expressed by the interaction of a dominant thermo-sensitive gene $(T)$ and complementary dominant

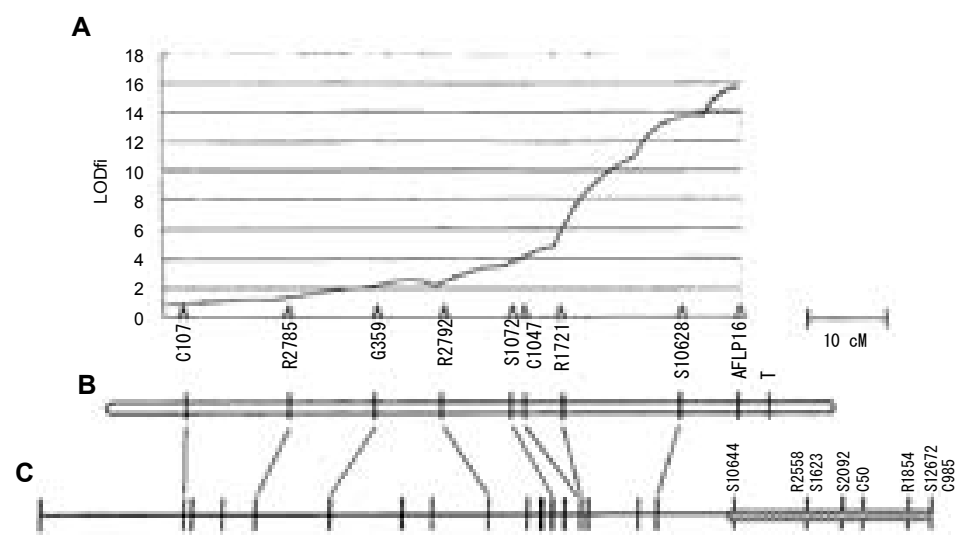

Fig. 2. The relationship between QTL analysis of DEFL and linkage analysis of thermo-sensitivity:. A: QTL analysis of DEFL on chromosome b, B: Linkage analysis of thermo-sensitivity as a single gene, C: Known Sorghum linkage map (Nagamura, Y. et al. 1998)

Note: Hatched region was fixed by the segments of Daikoukaku. 
photoperiod sensitivity genes $\left(D_{1}, D_{2}\right)$. The locus for $T$ was estimated to be on chromosome 6 at $4.0 \mathrm{cM}$ from AFLP16 marker. These results will be useful for genetic and breeding studies in sorghum.

\section{References}

1. Adachi, E. et al. (1999) Investigation method on heading characteristics in study of hypothetical genes controlling young panicle formation in sorghum. Kinki sakumotu-ikushu kenkyu (Kinki J. Crop Sci. and Breed.), 44, 5-8 [In Japanese with English summary].

2. Iwahara, Y. (2001) Study on thermo-sensitivity gene controlling young panicle formation in sorghum, Sorghum bicolor Moench. MS Thesis in Osaka Prefecture University. [In Japanese].

3. Kasuga, S., Gau, M. and Ogihara, H. (1992) Studies on the hybrid sorghum breeding. 3. On maturity genes of parental lines those appear overdominance. Jap. J. Breed. 42, Suppl.1, 262-263 [In Japanese].

4. Maeji, K. (2001) Study on controlling young panicle formation by treatments of daylength and temperature in sorghum, Sorghum bicolor Moench. MS Thesis in Osaka Prefecture University. [In Japanese].

5. Major D. J. et al. (1990) Temperature and photoperiod effects mediated by the sorghum maturity genes. Crop Sci., 30, 305-310.

6. Miller, F. R. et al. (1968) Effect of tropical photoperiods on the growth of sorghum when grown in 12 monthly plantings. Crop Sci., 8, 499-502.

7. Nagamura, Y. et al. (1998) Syntenic regions between rice and sorghum genomes. Proc. Intern. Workshop, Utilization of Transgenic plant and genome analysis in forage crops, NGRI Working Report 1998-9, 97-103.

8. Nakatsu, S. et al. (2004) AFLP marker linked to the thermosensitivity gene controlling sorghum flower initiation. Grassl. Sci., 50, Suppl., 266-267 [In Japanese].

9. Nakatsu, S. et al. (2004) Identification of chromosomal location of AFLP-16 marker linked to the sorghum thermo-sensitivity genen. Grassl. Sci., 50, Suppl., 268-269 [In Japanese].

10. Quinby, J. R. (1967) The maturity genes of sorghum. In "Advances in Agronomy XIX" Norman,A.G.(ed.), Academic Press Inc., New York, USA, 267-305.

11. Quinby, J. R. et al. (1973) Influence of temperature and photoperiod on floral initiation and leaf number in sorghum. Crop Sci., 13, 243-246.

12. Rooney, W. L. \& Aydin, S. (1999) Genetic control of a photoperiod-sensitive response in Sorghum bicolor (L.) Moench. Crop Sci., 39, 397-400.

13. Tarumoto, I. (1969) Studies on forage sorghum breeding. VI. Combining ability of forage yield and its components in $\mathrm{F}_{1}$ hybrids of "MS-HE" combination type. Jap. J. Breed., 19,
378-384 [In Japanese with English summary].

14. Tarumoto, I. (1971) Studies on breeding forage sorghum by utilizing heterosis. Bul. Chugoku Nat. Agr. Exp. Sta., A19, 21-138 [In Japanese with English summary].

15. Tarumoto, I. et al. (1997) Hypothetical genes controlling young panicle formation in sorghum. Jap. J. Breed., 47, Suppl.1, 145 [In Japanese].

16. Tarumoto, I. et al. (2000) Analysis of genetic variability in flowering habit and related genes in sorghum, Sorghum bicolor (L.) Moench. Breed. Res., 2, 59-65 [In Japanese with English summary].

17. Tarumoto, I. et al. (2003) Inheritance of a thermo-sensitivity gene controlling flower initiation in sorghum Breed. Sci., 53, 353-357.

18. Tarumoto, I. et al. (2003) Inheritance of photoperiod sensitivity genes controlling flower initiation in sorghum, Sorghum bicolor Moench. Grassl. Sci., 51, 55-61.

19. Yamada, T. (2002) Study on photoperiod sensitivity genes flower initiation in sorghum, Sorghum bicolor Moench. MS thesis, Osaka Prefecture University [In Japanese].

20. Yanase, M. et al. (2000) Studies on the floral initiation in sorghum. 1. Effects of day length and night temperature on flowering habit of sorghum varieties with dominant thermosensitivity gene. Kinki J. Crop Sci. and Breed., 45, 19-23 [In Japanese with English summary].

21. Yanase, M. \& Tarumoto, I. (2003) Studies on the flowering habit in sorghum. 2. Critical daylength and its sensitivity time of Kazetachi with a critical daylength. Grassl. Sci., 49, 170173 [In Japanese with English summary].

22. Yanase, M. et al. (2005) Effects of genes $T, D_{1}$ and $D_{2}$, which regulate flower initiation, and maturity genes $M a_{1}-M a_{4}$ on the heading response in Sorghum. Grassl. Sci., 51, 67-72 [In Japanese with English summary].

23. Uozumi, S. et al. (2001) Effects of night temperature treatments on the panicle initiation and final leaf number of sorghum (Sorghum bicolor Moench) inbred strain 932233. Grassl. Sci., 47, 145-150 [In Japanese with English summary].

24. Uozumi, S. et al. (2001) Effects of night temperature treatments on the panicle initiation and final leaf number of some sorghum (Sorghum bicolor Moench) varieties. Grassl. Sci., 47, 139-144 [In Japanese with English summary].

25. Uozumi, S. et al. (2001) Effects of air temperature treatments on the same characters related to heading in sorghum (Sorghum bicolor Moench). Grassl. Sci., 47, 484-490 [In Japanese with English summary].

26. Uozumi, S. (2003) Physiological studies on influence of daylength aand temperature to flowering response in sorghum, Sorghum bicolor Moench. Doctor thesis, Osaka Prefecture University [In Japanese].

27. Venuto, B. \& Kindiger, B. (2008) Forage and biomass feedstock production from hybrid forage sorghum and sorghumsudangrass hybrids. Grassl. Sci., 54, 189-196. 